Jurnal Kejaora: Jurnal Kesehatan Jasmani dan Olah Raga

ISSN: 2541-5042 (Online)

ISSN: 2503-2976 (Print)

Volume 5 Nomor 1, Edisi April 2020

\title{
KEMAMPUAN GURU PENJASOR MENERAPKAN KURIKULUM 2013 DALAM PEMBELAJARAN PADA SISWA KELAS X SMAN 3 SALAHUTU
}

\author{
Mieke Souisa ${ }^{1}$, Jacob Anaktototy ${ }^{2}$, Dwi Annisa ${ }^{3}$ \\ 1,2,3 Universitas Pattimura \\ Email:ms.souisa1512@gmail.com¹, jopi.anaktototy18@gmail.com², dwiannisa997@gmail.com³ \\ DOI: https://doi.org/10.36526/kejaora.v5i1.856
}

\begin{abstract}
ABSTRAK
Saat ini Kurikulum 2013 telah sah digunakan dalam pembelajaran, demikian pula pada matapelajaran pendidikan jasmani, namun belum nampak dalam realita penerapannya dilapangan. Berdasarkkan penelitian terdahulu yang dilaksanakan bagi guru penjasor pada beberapa sekolah dikota Ambon, ternyata masih saja ada sekolah yang menerapkan pembelajaran dengan kurikulum 2013 hanya sebagai cover saja, tetapi sesungguhnya dalam proses pembelajaran masih menerapkan prosedur KTSP. Tujuan dari penelitian ini yaitu "untuk mengetahui kemampuan guru pendidikan jasmani mengelola pembelajaran pada siswa kelas X SMA Negeri 3 Salahutu Kabupaten Maluku Tengah". Hal ini bertujuan untuk mendapatkan fakta tentang bagaimana kemampuan guru pendidikan jasmani dan olahraga di sekolah SMA Negeri 3 Salahutu Kabupaten Maluku Tengah melaksanakan proses pembelajaran di kelas dengan menerapkan kurikulum 2013. Metode yang digunakan dalam penelitian ini yaitu deskriptif kualitatif, dengan teknik pengumpulan data yang digunakan dalam penelitian ini yaitu; (1) observasi, (2) Dokumentasi, (3) wawancara, dan (4) triangulasi. Sedangkan teknik analisa data yang digunakan peneliti yaitu analisis reduksi data (data reduction) dari Miles dan Huberman. Hasil penelitian menunjukkan bahwa (1) kemampuan DT dalam kegiatan pendahuluan dikategorikan rendah, dengan rata-rata kemampuan sebesar $35 \%$ dari skor maximal 20. (2) Kemampuan DT dalam kegiatan inti pembelajaran dikategorikan rendah, dengan rata-rata 37\% dari skor maksimal 90. (3) Kemampuan DT dalam kegiatan menutup pembelajaran dikategorikan cukup, dengan rata-rata $34 \%$ dari skor maksimal 10 . Sedangkan secara umum kemampuan guru dalam mengelola pembelajaran sebesar 42.50\% dari skor maksimal 120. Sehingga dapat dikatakan bahwa kemampuan DT dalam mengelola pembelajaran pendidikan jasmani masih dikategorikan rendah.
\end{abstract}

Kata Kunci: Kemampuan guru pendidikan jasmani, Mengelola pembelajaran, Kurikulum 2013

\section{PENDAHULUAN}

Pendidikan merupakan salah satu aspek yang sangat berpengaruh terhadap kemajuan bangsa untuk meningkatkan mutu Sumber Daya Manusia. Hal ini dikarenakan pendidikan memiliki peran yang signifikan dan pranata utama dalam menyiapkan sumber daya manusia. Pemerintah Indonesia menyusun dan mengembangkan program untuk meningkatkan mutu pendidikan, salah satunya dengan menyempurnakan kurikulum yang mengacu pada landasan yuridis yaitu pancasila dan UUD 1945. Sebagaimana telah kita ketahui bersama bahwa Kurikulum merupakan seperangkat rencana dan pengaturan mengenai isi dan bahan pelajaran serta cara yang digunakan sebagai pedoman penyelenggaraan kegiatan pembelajaran.

Maka saat ini kurikulum 2013 telah sah dilaksanakan dalam pembelajaran pada semua jenjang pendidikan dasar dan menengah di seluruh pelosok tanah air. Selain adanya perubahan kurikulum dalam bidang pendidikan, guru juga dituntut untuk mampu menyebar informasi yang baik, tentunya berupa informasi edukatif. Oleh karenanya, pola interaksi antara guru dan peserta didik yang berlangsung tidak sesuai dengan kurikulum 2013, yang telah tertuang dalam Rencana Pelaksaan Pembelajaran (RPP), dapat mengakibatkan siswa pasif dalam proses pembelajaran. Kurikulum 2013 juga merupakan kurikulum yang di terapkan 
Jurnal Kejaora: Jurnal Kesehatan Jasmani dan Olah Raga

ISSN: 2541-5042 (Online)

ISSN: 2503-2976 (Print)

Volume 5 Nomor 1, Edisi April 2020

pemerintah untuk melengkapi kurikulum sebelumnya.

Harapan kita dengan diterapkannya kurikulum 2013, maka pembelajaran yang dilaksanakan akan efektif, karena output dari penerapan kurikulum 2013 sendiri yaitu menghasilkan insan Indonesia yang produktif dan kreatif, inovatif dan efektif melalui penguatan sikap, keterampilan dan pengetahuan yang terintegrasi. Kurikulum 2013 lebih mengutamakan pembinaan kompetensi dan karakter peserta didik. Namun sayangnya, fakta dilapangan memperlihatkan perbedaan dalam penerapan kurikulum, dimana belumlah sesuai dengan prosedur penerapan kurikulum 2013 dalam pembelajaran.

Hal inipun terlihat dari penelitian terdahulu, yang dilakukan dikota Ambon bagi beberapa guru pendidikan jasmani dan olahraga (yang dijadikan subyek penelitian) pada beberapa sekolah menengah pertama, dimana masih ada subyek yang menggunakan kurikulum 2013 namun proses pembelajaran masih menggunakan KTSP. Jikalau beberapa subyek yang berasal dari beberapa sekolah dikota Ambon, yang merupakan barometer kualitas pendidikan saja menerapkan kurikulum 2013 dalam pembelajaran seperti itu, bagaimana dengan sekolah-sekolah yang berada dikabupaten, kecamatan, bahkan pulau-pulau terluar di provinsi Maluku?

Berdasarkan uraian di atas, maka ketika peneliti melihat bahwa di SMA Negeri 3 Salahutu Kabupaten Maluku tengah masih terdapat kekurangan-kekurangan dalam proses pembelajaran, khususnya pada pendidikan jasmani dan olahraga. Adapun kekurangan-kekurangan yang Peneliti peroleh secara garis besar dalam pembelajaran yang dilaksanakan oleh guru didalamnya terjadi pola yang searah, sehingga monoton antara guru dan siswa saja. Kemudian mencari pemecahan terhadap berbagai masalah pembelajaran yang ditemukan Untuk memperbaiki keadaan ini perlu adanya perbaikan kualitas sumber daya manusia khususnya guru penjasor yang ada di semua jenjang sekolah.

Atas dasar inilah maka peneliti terinspirasi untuk mendalami masalah ini

dalam sebuah penelitian yang berjudul "Kemampuan guru penjas dalam menerapkan kurikulum 2013 pada siswa kelas X SMA Negeri 3 Salahutu".

\section{Kegiatan Guru dalam Pembelajaran \\ Secara umum pelaksanaan} pembelajaran atau sering dikenal dengan kegiatan belajar mengajar merupakan implementasi dari apa yang telah direncanakan oleh guru dalam program pembelajaran, sehingga diharapkan guru mampu untuk menjalankan proses pembelajaran sesuai dengan yang telah direncanakan, agar benar-benar pembelajaran yang dilaksanakan oleh guru terarah dengan baik sehingga tujuan pembelajaran dapat terealisasikan sesuai dengan harapan. Trisnawati (dalam Anaktototy dan Souisa 2018) mengemukakan bahwa dalam melaksanakan pembelajaran secara garis besar terdapat 3 (tiga) kegiatan utama yang harus dijalankan, antaralain; (1) kegiatan pendahuluan, (2) kegiatan inti, dan (3) kegiatan penutup.

Selanjutnya, ketiga jenis kegiatan diatas dapat dijelaskan bahwa yang dimaksud dengan kegiatan pendahuluan merupakan kegiatan untuk membuka kelas, yang bertujuan agar siswa terkondisikan untuk siap melaksanakan proses belajar mengajar, sesuai dengan isi materi yang telah dikemas oleh guru. Kemudian kegiatan inti merupakan proses menyajikan materi. Pada bagian ini guru harus dituntut menguasai materi yang akan disajikan bagi siswa, bahkan guru sendiri harus memiliki wawasan yang selalu up-to date, sehingga siswa tidak menjadi bosan karena guru hanya terikat dengan buku pegangan. Sedangkan kegiatan penutup merupakan rangkaian kegiatan antara guru bersama peserta didik (kelompok maupun individu) melakukan refleksi, yang bertujuan untuk mengevaluasi berbagai hal, diantaranya: (a) Seluruh rangkaian aktifitas pembelajaran dan hasil-hasil yang diperoleh untuk selanjutnya secara bersama menemukan manfaat yang diperoleh, (b) Memberikan umpan balik terhadap proses dan hasil pembelajaran, (c) Melakukan kegiatan tindak lanjut dalam bentuk pemberian tugas, baik individu maupun 
Jurnal Kejaora: Jurnal Kesehatan Jasmani dan Olah Raga

ISSN: 2541-5042 (Online)

ISSN: 2503-2976 (Print)

Volume 5 Nomor 1, Edisi April 2020

kelompok, (d) Menginformasikan kegiatan pembelajaran untuk pertemuan berikutnya.

\section{Kurikulum 2013}

Undang undang nomor 20 tahun 2003 tentang Sistem Pendidikan Nasional, kurikulum merupakan seperangkat rencana dan pengaturan mengenai tujuan, isi, dan bahan pelajaran serta cara yang digunakan sebagai pedoman penyelenggaraan kegiatan pembelajaran untuk mencapai tujuan pendidikan tertentu (Syarifudin dan Andriatoni 2016). Mulyasa (2013) mengemukakan bahwa tema kurikulum 2013 adalah menghasilkan insan Indonesia yang produktif, kreatif, inovatif, afektif melalui penguatan sikap, keterampilan dan pengetahuan yang terintegrasi. Untuk mewujudkan hal tersebut, dalam implementasi kurikulum, guru di tuntut untuk;(1) merancang pembelajaran efektif dan bermakna, (2) mengasosiasikan pembelajaran, (3) Memilih dan Menentukan Pendekatan Pembelajaran,

Melaksanakan pembelajaran, pembentukan kompetensi dan karakter.

\section{METODE}

Agar tujuandalam penelitian ini dapat tercapai,dimana memperoleh data tentang kemampuan guru pendidikan jasmani dalam mengelola proses pembelajaran pada siswa kelas X SMA Negeri 3 Salahutu Kabupaten Maluku Tengah dengan Implementasi kurikulum 2013, maka penelitian ini diselesaikan secara deskriptif dengan menggunakan pendekatan kualitatif, dimana data yang diperoleh dianalisis secara kualitatif. Maka Maksum (2012) mengemukakan bahwa penelitian deskriptif merupakan penelitian yang dilakukan untuk menggambarkan gejala, fenomena atau peristiwa tertentu, sehingga pengumpulan data dilakukan untuk mendapatkan informasi terkait dengan fenomena, kondisi, atau variable tertentu, dan tidak dimaksudkan untuk melakukan pengujian hipotesis.

Sedangkan pendekatan yang digunakan dalam penelitian ini yaitu kualitatif. Maksum (2012) mengemukakan bahwa pendekatan kualitatif merupakan pendekatan penelitian yang berusaha mendeskripsikan dan memahami suatu fenomena secara

mendalam dengan peneliti sebagai instrument utama.

Untuk memperoleh data dilapangan, maka peneliti menggunakan 4 (empat) jenis teknik pengumpulan data, antaralain; (1) Observasi, (2) Dokumentasi, (3) Wawancara, dan (4) Triangulasi.

Sedangkan untuk menganalisis data, setelah data berhasil dikumpulkan peneliti menggunakan teknik analisis reduksi data (data reduction) dari Miles dan Huberman (dalam Sugiyono, 2013).

Data yang diperoleh adalah hasil observasi yang dilaksanakan ketika guru pendidikan jasmani melaksanakan proses pembelajaran dan diperkuat dengan data wawancara dan dokumentasi yang di peroleh pada saat penelitian berlangsung, setelah itu seluruh data yang diperoleh dari hasil observasi, dokumentasi, dan wawancara dianalisis secara silang, sehingga hasilnya menjadi dasar agar memudahkan dalam menarik kesimpulan dalam penelitian ini.

\section{HASIL DAN PEMBAHASAN}

Berdasarkan data yang diperoleh peneliti tentang kemampuan guru dalam mengelola kegiatan pembelajaran dengan materi penyalagunaan NPZA dan bahayanya, dilapangan menunjukkan bahwa dari total skor maximal yang harus diperoleh DT adalah 120, dan berdasarkan analisis kemampuan yang ditunjukkan DT, secara umum dapat dilihat dalam diagram 1.

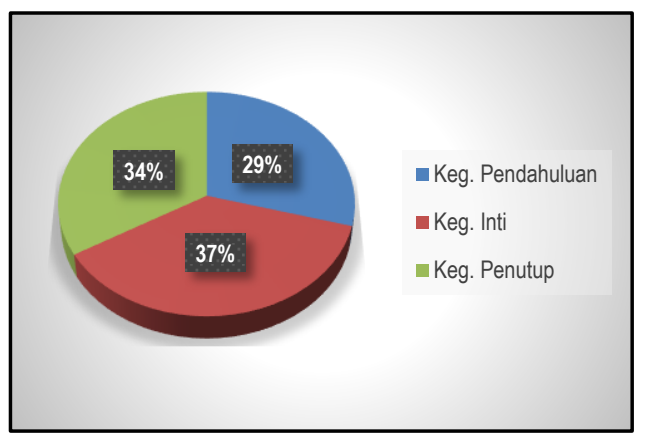

Diagram 1. Kemampuan DT Mengelola Pembelajaran

Berdasarkan diagram 1 tentang
kemampuan DT dalam mengelola
pembelajaran secara umum, maka dapat
dipaparkan kemampuan per kegiatan sebagai
berikut:


Jurnal Kejaora: Jurnal Kesehatan Jasmani dan Olah Raga

ISSN: 2541-5042 (Online)

ISSN: 2503-2976 (Print)

Volume 5 Nomor 1, Edisi April 2020

\section{Kegiatan Pendahuluan}

Pada kegiatan pendahuluan dalam pembelajaran dapat dijelaskan rinci dalam aspek yang pertama yaitu pengorganisasian kelas (PK) memperoleh skor 2 karena peserta didik tidak memperhatikan guru pendidikan jasmani atau DT yang sedang berbicara didepan kelas, kemudian pada aspek yang kedua menunjukan manfaat materi pembelajaran (M3P) memperoleh skor 1 karena dari hasil observasi yang dilihat guru tidak mengaitkan manfaat pembelajaran kepada siswa, Untuk aspek ketiga yaitu mengaitkan materi yang akan di pelajari dengan pengalaman peserta didik atau dengan materi sebelumnya (M2P2M) memperoleh skor 2, dikarenakan dalam observasi berlangsung tidak melihat guru mengaitkan materi pembelajaran dengan pengalaman peserta didik.. Kemudian pada aspek keempat yaitu menyampaikan motivasi guru atau menyampaikan manfaat pembelajaran kepeda peserta didik (M2M3P) memperoleh skor 2 karena kurang maksimal dalam menyampaikan manfaat pembelajaran kepada peserta didik. Sehingga secara rinci peta kemampuan DT dalam kegiatan pendahuluan dapat dilihat dalam diagram 2 dibawah ini.

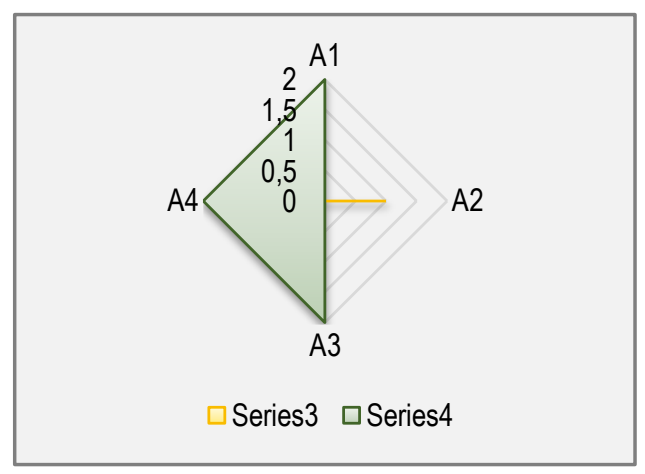

Diagram 2. Kemampuan DT dalam Kegiatan Pendahuluan

Adapun hasil wawancara yang diperoleh dari kelima peserta didik tersebut dapat disimpulkan DJ melaksanakan aspek ketiga yaitu mengaitkan materi yang akan di pelajari dengan pengalaman peserta didik atau dengan materi sebelumnya (M2P2M), DT mengaitkan pembelajaran tentang

NAPZA dan obat-obat berbahaya dengan cara menyampaikan bahaya penyalahgunaan NAPZA apabila dikonsumsi, akan tetapi penyampaian yang diberikan oleh DT dalam kegiatan inti pembelajaran bukan pada kegiatan pendahulan atau awal pembelajaran.

\section{Kegiatan Inti Pembelajaran}

Pada kegiatan inti pembelajaran dapat dilihat secara rinci dimana aspek pertama, menunjukan penguasaan materi pembelajaran (MPMP) memperoleh skor 2 dikarenakan dalam menyampaikan materi DT masih terlihat memegang buku dan membacanya, tetapi untuk aspek kedua, membuat kaitan antara materi dengan realita atau dengan pengatahuan lainya (MKMR) di beri skor 4 karena terlihat pada hasil observasi yang dilakukan, DT mengaitkan pembelajaran dengan pengetahuan lainya contohnya saja pembelajaran tentang narkoba, DT memberikan contoh orang terkena narkoba dan sangat berbahaya ketika kita sudah tercandu NAPZA.

Untuk aspek ketiga yaitu menyajikan materi secara jelas, terstruktur dan mudah dipahami dalam inti pembelajaran (M2SJ) skor yang diperoleh 3 karena peneliti melihat proses penyampaian materi jelas, akan tetapi tidak terstruktur dengan baik akhirnya peserta didik tidak memperhatikan proses pembelajaran yang di laksanakan. Kemudian pada aspek keempat yaitu melaksanakan pembelajaran sesuai dengan kompetensi dan indikator (tujuan) yang dicapai secara karakteristik peserta didik (MPKI) memperoleh skor 1 karena dalam observasi tersebut peneliti tidak melihat pemberian materi sesuai dengan kompetensi dan indikator (tujuan) yang akan dicapai dalam proses pembelajaran.

Untuk aspek kelima yaitu menguasai kelas (MK) memperoleh skor 1, dari hasil observasi yang peneliti lihat tidak adanya penguasaan kelas karena dalam proses pembelajaran sebagian siswanya tidur dan bercerita, mereka tidak memperhatikan pembelajaran yang di berikan oleh guru. Untuk aspek keenam sampai dengan sepuluh yaitu menfasilitasi peserta didik untuk mengamati (MPM), memancing dan 
Jurnal Kejaora: Jurnal Kesehatan Jasmani dan Olah Raga

ISSN: 2541-5042 (Online)

ISSN: 2503-2976 (Print)

Volume 5 Nomor 1, Edisi April 2020

mendorong peserta didik untuk bertanya (M2PB), memfasilitasi peserta didik untuk mengumpulkan informasi atau mengamati (MPMI), memfasilitasi peserta didik menganalisis atau menalar atau mengasosiasi (MPM2), memfasilitasi peserta didik mengkomunikasikan hasil kerja (MPMH) memperoleh skor 1, karena DT tidak melaksanakan kegiatan inti pembelajaran sesuai dengan hasil observasi, siswa tidak dibagi dalam kelompok-kelompok kecil sehingga mereka tidak berpatisipasi dalam proses pembelajaran. Untuk aspek sebelas yaitu menggunakan media secara efektif dan efisien (M2E2) memperoleh skor 2 karena dalam proses pembelajaran sumber media yang digunakan untuk mengamati hanyalah buku paket untuk kelas $\mathrm{X}$ sedangkan gambar atau video tidak di perlihatkan dalam proses mengamati.

Selanjutnya untuk aspek kedua belas sampai empat belas yaitu melibatkan peserta didik dalam pemanfaatan sumber belajar (MPPS), terbuka terhadap respon peserta didik (T2RP), menunjukan hubungan antara pribadi yang kondusif (MHPK) memperoleh skor 3, dari ketiga aspek ini dilaksankan hanya saja kurang efektif di karenakan dalam proses pembelajaranya monoton dan siswa tidak diberi kesempatan untuk bertanya terkait dengan materi yang diajarkan, tetapi DT memberikan penjelasan terkait dengan materi yang diajarkan.

Untuk aspek kelima belas yaitu melakukan pembelajaran yang memungkinkan tumbuhnya kebiasaan positif atau nurturant effect (MPMTK) memperoleh skor 4 karena dalam proses pembelajaran DT menceritakan pengalaman terkait dengan bahaya narkoba ketika kita kecanduan mengonsumsinya, sedangkan untuk aspek keenam belas yaitu memantau atau menilai kemampuan belajar peserta didik (MKP) memperoleh skor 2 karena peneliti melihat proses pembelajaran tidak menggunakan diskusi kelompok. Selain itu dalam pembelajaran berlangsung tidak melihat DT menilai kemajuan belajar peserta didik. Aspek ketujuh belas yaitu menggunakan bahan lisan dan tulis, secara jelas, baik dan benar (MBLT) memperoleh skor 3 karena buku yang dijadikan sebagai pedoman dalam

pembelajaran baik akan tetapi kurang efektif diterapkan karena peserta didik hanya melihat bahasa dari buku, selain itu untuk aspek yang terakhir atau kedelapan belas menggunakan waktu secara efektif (MWSE) memperoleh skor 4 dikarenakan DT memanfaatkan waktu dalam proses pembelajaran dengan baik atau sesuai dengan alokasi waktu. Sehingga peta kemampuan DT dalam melaksanakan kegiatan inti pembelajaran, dapat dilihat dalam diagram 3 dibawah ini.

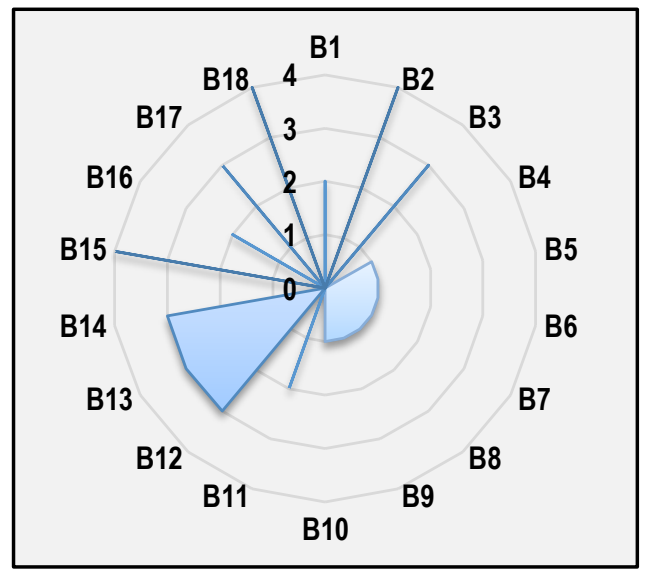

Diagram 3. Kemampuan DT dalam Kegiatan Inti Pembelajaran

Adapun hasil wawancara dengan kelima peserta didik terkait dengan aspek keenam sampai dengan ke sepuluh dapat disimpulkan DT melaksanakan pembelajaran dengan pendekatan saintifik, tetapi bagian pengamatannya saja yang dilaksanakan, sedangkan bertanya, mengumpulkan informasi, menalar dan mengkomunikasikan tidak dilaksanakan. Dalam pertemuan tentang NAPZA tidak ada kegiatan pengamatan yang dilakukan oleh guru penjasor tersebut.

\section{Kegiatan Penutup}

Pada kegiatan menutup pembelajaran dapat di jelaskan bahwa terdapat 2 (dua) jenis kegiatan antaralain untuk aspek pertama yaitu melakukan refleksi atau membuat rangkuman dengan melibatkan peserta didik (MR2MP) memperoleh skor 3 karena dalam proses pembelajaran guru melaksanakan refleksi dalam bentuk Tanya jawab kepada siswa tetapi dalam proses Tanya jawab 
Jurnal Kejaora: Jurnal Kesehatan Jasmani dan Olah Raga

ISSN: 2541-5042 (Online)

ISSN: 2503-2976 (Print)

Volume 5 Nomor 1, Edisi April 2020

tersebut kurang efektif. Selain itu, untuk aspek kedua yaitu melaksanakan tindak lanjut berupa arahan, penguatan atau tugas sebagai bagian remedial/pengayaan (MTLA) memperoleh skor 1 karena dalam kegiatan akhir pembelajaran tidak adanya pemberian tugas atau arahan terkait dengan materi yang didapat. Lebih jelasnya, hasil ini dapat dilihat dalam peta kemampuan dalam diagram 4 .

Untuk mendukung hasil observasi tersebut maka hasil wawancara dari kelima siswa dapat disimpulkan bahwa, pada aspek pertama DT melaksanakn evaluasi dalam bentuk Tanya jawab antara guru dan peserta didik, tetapi dalam kegiatan evaluasi kurang efektif karena pada kegiatan evaluasi sendiri guru memberikan pertanyaan yang terdapat dalam buku paket pendidikan jasmani kelas $X$ SMA Negeri 3 Salahutu Kabupaten Maluku Tengah.

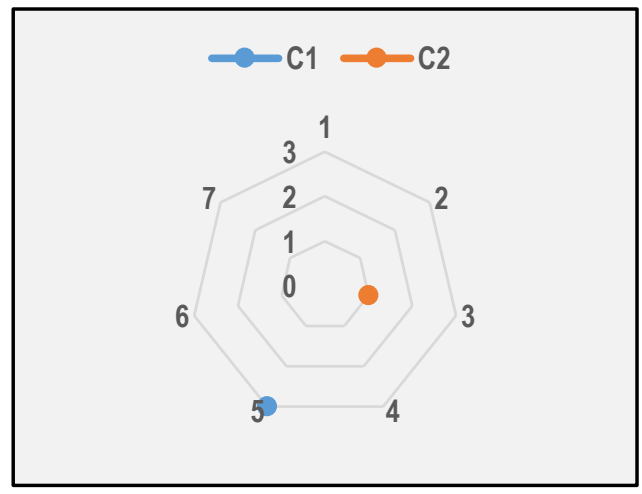

Diagram 4. Kemampuan DT dalam Kegiatan Menutup Pembelajaran

\begin{tabular}{lrrr}
\multicolumn{2}{c}{ Berdasarkan hasil analisis } \\
kemampuan DT dalam & mengelola \\
pembelajaran, mulai dari & kegiatan
\end{tabular} pendahuluan memperoleh skor 35 atau sebesar $29 \%$, kegiatan inti pembelajaran memperoleh skor 44 atau sebesar 37\%, dan kegiatan menutup pembelajaran memperoleh skor 40 atau sebesar $34 \%$, seperti dalam diagram 1 diatas dengan total nilai 42.5 yang diperoleh dari total skor perolehan sebesar 51 dibagi dengan total skor maksimal sebesar 120. Sehingga rata-rata kemampuan DT dalam mengelola pembelajaran masih dikategorikan "Rendah".

\section{KESIMPULAN}

Berdasarkan hasil yang diperoleh dalam penelitian ini, maka dapat di simpulkan bahwa (1) kemampuan DT dalam kegiatan pendahuluan dikategorikan rendah, dengan rata-rata kemampuan sebesar $35 \%$ dari skor maximal 20. (2) Kemampuan DT dalam kegiatan inti pembelajaran dikategorikan rendah, dengan rata-rata $37 \%$ dari skor maksimal 90. (3) Kemampuan DT dalam kegiatan menutup pembelajaran dikategorikan cukup, dengan rata-rata $34 \%$ dari skor maksimal 10.

Selanjutnya, secara umum kemampuan guru dalam mengelola pembelajaran sebesar $42.50 \%$ dari skor maksimal 120. Sehingga dapat dikatakan bahwa kemampuan DT dalam mengelola pembelajaran pendidikan jasmani masih dikategorikan rendah.

\section{SARAN}

Berdasarkan hasil penelitian yang telah dibahas pada bagian sebelumnya, maka saran yang disampaikan sebagai berikut:

1. Perlu adanya perbaikan kualitas Sumber Daya Manusia (SDM) dalam hal ini guru pendidikan jasmani dan olahraga yang ada di semua jenjang sekolah dalam kaitannya dengan penerapan kurikulum 2013 dalam pembelajaran pendidikan jasmani dan olahraga.

2. Perlu adanya penelitian-penilitian lajutan di bidang pendidikan jasmani, sehingga dapat memperoleh data real tentang penerapan kurikulum 2013 dalam pembelajaran khususnya dimata pelajaran pendidikan jasmani dan olahraga, dikabupaten dan kota di provinsi Maluku, demi pengembangan dan perbaikan mutu pendidikan jasmani dan olahraga kedepannya.

\section{UCAPAN TERIMA KASIH}

Peneliti menyampaikan ucapan terima kasih dan penghargaan yang setingitingginya kepada Kepala Sekolah Menengah Atas Negeri 3 Salahutu Kabupaten Maluku Tengah, yang telah mengijinkan peneliti untuk melakukan penelitian ini. Demikian pula guru pendidikan Jasmani dan Olahraga SMA Negeri 3 Salahutu, serta siswa/siswi kelas $X$ 
Jurnal Kejaora: Jurnal Kesehatan Jasmani dan Olah Raga

ISSN: 2541-5042 (Online)

ISSN: 2503-2976 (Print)

Volume 5 Nomor 1, Edisi April 2020

SMA Negeri 3 Salahutu yang telah bersedia dan berpartisipasi aktif dalam proses pembelajaran sekaligus penelitian ini.

\section{DAFTAR PUSTAKA}

Afrizal. (2016). "Metode Penelitian Kualitatif". Jakarta: PT Rajagrafindo Persada.

Anaktototy, J. dan Souisa, M. (2018). "Analisis Kemampuan Guru Pendidikan Jasmani Dalam Mengelola Pembelajaran Pada Jenjang Sekolah Menegah Pertama Di Kota Ambon". Ambon: Universitas Pattimura.

Maksum, A. (2012). "Metodologi Penelitian". Dalam Olahraga. Surabaya:Unesa University Press.

Moleong, L.J. (2012). "Metodologi Penelitian Dalam Olahraga". Surabaya: UnesaUniversity Press.

Mulyasa, E. (2013). "Menjadi Guru Profesional". Menciptakan Pembelajaran Kreatif dan Menyenangkan. Bandung: PT. Remaja Rosdakarya.

Mulyasa, H.E. (2014). "Pengembangan dan Implementasi Kurikulum 2013". Bandung: PT. Remaja Rosdakarya.

Nurdin S. dan Ariantoni. (2016). Kurikulum dan Pembelajaran. Jakarta: PT Raja Grafindo Persada.

Prastowo, A. (2011). "Metode Penelitian Kualitatif: dalam Perspektif Rancangan Penelitian". Cet. I. Jakarta: Departemen Pendidikan Nasional.

Suherman, A. (2000). "Dasar-Dasar Pendidikan Jasmani dan Kesehatan". Departemen Pendidikan Jasmani, Jakarta.

Sugiyono. (2013). "Memahami Penelitian Kualitatif'. Bandung: Alfabeta.

Samsudin. (2014). "Media Pembelajaran Pendidikan Jasmani". Jakarta: PT Fajar Interpratama Mandiri.

Yani A. (2014). "Mindset Kurikulum 2013". Bandung: Alfabeta 